\title{
Economic Losses' Estimation of carcass and Organ Condemnations From Slaughter Cattle in Thailand, Pará State, Brazilian Amazon
}

\author{
Gerlane Nunes Noronha \\ Federal University of Pará (UFPA), Brazil
}

Marcos Antônio Souza dos Santos, Washington Luiz Assunção Pereira, Alexandre do Rosário Casseb

Federal Rural University of Amazon (UFRA), Brazil

Andréia Santana Bezerra, José de Brito Lourenço Júnior

Federal University of Pará (UFPA), Brazil

Received: August 1, 2019 Accepted: Sep.8, $2019 \quad$ Published: Sep. 9, 2019

doi:10.5296/jas.v7i4.15181～URL: https://doi.org/10.5296/jas.v7i4.15181

\begin{abstract}
The article identifies the main pathologies found and estimates the economic losses generated in a slaughterhouse in the Thailand municipality, Pará, during the period from March 2010 to October 2014. 55,169 animals were slaughtered, with total economic losses of $\mathrm{R} \$ 1,221,035.90$ and ischemia was the most frequent lesion $(41.86 \%)$. The most frequent condemnation organs were lungs $(48.75 \%)$, kidneys $(41.66 \%)$ and liver $(3.61 \%)$, which produced economic loss of $\mathrm{R} \$ 76,405.65$ (6.26\%). Tuberculosis was the main cause of carcass condemnation, responsible for $\mathrm{R} \$ 872,783.64$ of economic losses. The bovine tuberculosis control can begin in production, with examinations on the farm to slaughter lines, with careful carcass inspection, as advocated by the National Program for the Control and Eradication of Animal Brucellosis and Tuberculosis (PNCEBT), which increases disease control and minimizes condemnations and economic losses at slaughter.
\end{abstract}

Keywords: Brazilian Amazon, livestock economics, beef, tuberculosis 


\section{Introduction}

Brazil is the largest exporter and second largest beef producer in the world (USDA, 2018). Since it represents an important part of Brazilian agribusiness, the sanitary hygiene of processing environment and meat product are fundamental factors to the import market requirements (MAPA, 2017). Measures to protect the consumers' health of animal products include ante-mortem and post-mortem inspection at slaughter, hygienic procedure adoption during meat processing, correct storage, transport in refrigerated trucks and marketing of cooled meat. This process is called sanitary inspection, and when organs and carcasses show abnormalities, they can be condemned, which causes economic losses for slaughterhouse and producers (Sarcinelli et al., 2007; Kale et al., 2011).

According to the Regulation on Industrial and Sanitary Inspection of Products of Animal Origin (RIISPOA), Brazilian legislation, decree 9.013 (Brasil, 2017), which establishes standards for the slaughter and processing of animal products, and provides three destinations, for carcasses, organs and viscera: release, condemnation and conditional use through cold, salting and heat. The greatest economic losses occur in the last two types of destination. In general, full condemnation is indicated for cases of generalized infestations. The release of the in natura carcass is predicted when a single calcified cyst is found after its excision.

RIISPOA (Brasil, 2017) requires sanitary inspection of all establishments that slaughter animals for consumption, which must be carried out by a team trained and coordinated by a veterinarian. This inspection can occur in three spheres: federal (Federal Inspection Service SIF), state (State Inspection Service - SIE) and municipal (State Inspection Service - SIM). The difference between them is the commercial scope, where SIF allows marketing within the whole country and even outside it, the SIE within the state and the SIM only in the municipality itself. Another implemented inspection system in Brazil is the Unified System of Attention to Agricultural Health - Suasa, in which inspected products can be marketed throughout the national territory when adopted by states, Distrito Federal and municipalities, as evidenced by inspection practices according to the Ministry of Agriculture, Livestock and Supply.

Small slaughterhouse, such as those submitted to municipal inspection, do not always have a structure for the processing of preserved, sausage and salted products, so the carcasses, viscera and organs that are partially or totally condemned according to the degree of injury, are destined to greyness, which increases the losses, since they do not have conditions for their conditional use.

Thus, this work identifies and analyzes the main causes of condemnation in the slaughterhouse in Thailand, Pará state; and also, measures the generated economic losses, as well as proposing possible solutions to minimize financial losses.

\section{Materials and Methods}

This work was carried out in the slaughterhouse of the Thailand municipality (2 $\left.2^{\circ} 56^{\prime} 44^{\prime \prime} \mathrm{S} / 48^{\circ} 57^{\prime} 14^{\prime \prime} \mathrm{W}\right)$ and area of 4,430 $\mathrm{Km}^{2}$ ), Northeast Pará Meso-region and Tomé-Açu Microregion, Pará state. Tailândia is located in north with Acará, east with 


\section{Macrothink}

Tomé-Açu, south with Ipixuna do Pará and west with Moju (Silva, 2011). The last population census showed that the population was estimated at 79,297 inhabitants, of whom about $26 \%$ reside in the rural area (IBGE, 2010).

Thailand has a herd of about 79,000 head of cattle (IBGE, 2018a), and animal health programs are run and monitored by the Agência de Defesa Agropecuária do Pará (ADEPARÁ, 2019), headquartered in Pará state's capital city. The municipality is classified as a free area of foot-and-mouth disease, with vaccination since 2013 (MAPA, 2018). The animals slaughtered in the slaughterhouse, with slaughter capacity for 60 cattle per day, are monitored through the SIM, regulated by Municipal Law 240/2009, by the Municipal Department of Agriculture, which has a team of veterinarians and two inspection agents.

In the estimation of condemnation losses, carcass weights and viscera were determined using the literature (IBGE, 2018b; Almeida et al., 2019), based on the prices of products sold in the local market in Thailand (Table 1). The real and dollar prices were corrected to eliminate the inflationary effect through the Fundação Getúlio Vargas (FGV, 2019) and the Consumer Price Index (IGP-DI) CPI) (US Inflation Calculator, 2019), respectively; both based on December 2018. The calculations of economic losses were made by the condemned items' sum, multiplied by the selling price.

Table 1. Viscera and carcass weight estimation and marketing prices in Thailand

\begin{tabular}{ccc}
\hline Item & Average weight $(\mathrm{kg})$ & Average price $(\mathrm{R} \$ / \mathrm{kg})^{1}$ \\
\hline Liver & $5.02^{2}$ & 12.06 \\
Heart & $1.73^{2}$ & 1.68 \\
Lung & $2.66^{2}$ & 8.89 \\
Stomach & $4.50^{2}$ & 5.08 \\
Tongue & $1.63^{2}$ & 1.27 \\
Kidney & $1.03^{2}$ & 1.27 \\
Spleen & $1.42^{2}$ & 9.52 \\
Carcass & $231.57^{3}$ & 10.84 \\
Head meat & $1.73^{2}$ & \\
\hline
\end{tabular}

${ }^{1}$ Note: Values corrected for December 2018 by the IGP-DI (FGV, 2019).

Source: $\left({ }^{2}\right)$ Almeida et al. (2019); $\left({ }^{3}\right)$ IBGE (2018b). 


\section{Ml Macrothink}

The pathologies that generated condemnations were diagnosed through visual inspection. Tuberculosis (TB), specifically, was identified by characteristic lesions of progressive formation of nodules in respiratory, pre-scapular and pectoral lymph nodes. At a later time, the macroscopic judgment was confirmed by complementary diagnostic methods such as histopathological and Polymerase Chain Reaction - PCR, in the Laboratory of Animal Pathology of the Federal Rural University of Amazonia - UFRA and Laboratory of Bacteriology of the Evandro Chagas Research Institute, respectively, in which $1.96 \%$ of samples for histopathology corresponded to inflammatory processes characteristic of TB and in PCR $4.25 \%$ with amplification profile for M. bovis species.

To evaluate the seasonality existence in the number of slaughtered animals and monthly slaughter percentage, ANOVA and Tukey test (5\%) were performed using SPSS software version 20.0 .

\section{Results and Discussion}

Data were obtained through slaughter and condemnation records of carcasses and bovine viscera between March 2010 and October 2014. During the survey period, 55,169 cattle were slaughtered, with females predominating $(92.28 \%)$ in relation to males. These animals come from 17 Pará's municipalities, most of them (58.99\%) from Thailand and some neighboring municipalities, which supply cattle for slaughter, such as Jacundá (12.85\%), Moju (11.14\%), and Goianésia (8.52\%). Other municipalities with more than $500 \mathrm{Km}$ from Thailand, or about seven travel hours, contribute less expressive amounts, such as Xinguara (0.04\%) and Rio Maria $(0.67 \%)$. The slaughter of adult animals was observed at 36 months of age $(81.32 \%)$, which is justified by the fact that the farmer sells animals for slaughter at a lower cost to the dealers. Of the total, the causes of viscera and carcass lesions were quantified, and the economic losses of the condemnations were calculated.

The ANOVA showed a difference in the number of animals slaughtered $(\mathrm{F}=2,611)$ and in the monthly slaughter rate $(\mathrm{F}=7,952)$, at a level of $5 \%$, evidencing seasonality existence in slaughter. Table 2 shows that October was the month with the highest slaughtering average. In April, lower averages and standard deviation with low coefficient of variation were obtained. The difference in slaughter, among the months' year is due to the increase in consumption, due to holidays and parties, in the second semester; for example, agricultural fair in September, Christmas and New Year. And also, the increase in purchasing power because of the thirteenth salary makes December with a higher percentage of slaughtered animals $(9.24 \%)$. 
Table 2. Animals slaughtered between March 2010 and October 2014

\begin{tabular}{|c|c|c|c|c|c|c|}
\hline Month & $\begin{array}{l}\text { Month } \\
\text { number }\end{array}$ & Heads & Percent $(\%)$ & Average & Standard deviation & $* \mathrm{CV}(\%)$ \\
\hline January & 4 & 3,720 & 7.87 & 930 & 50 & 5.57 \\
\hline February & 4 & 3,670 & 7.76 & 918 & 48 & 5.40 \\
\hline March & 5 & 4,828 & 8.17 & 966 & 19 & 2.02 \\
\hline April & 5 & 4,415 & 7.47 & 883 & 7 & 0.82 \\
\hline May & 5 & 4,882 & 8.26 & 976 & 27 & 2.84 \\
\hline Jun & 5 & 4,877 & 8.25 & 975 & 29 & 3.03 \\
\hline July & 5 & 5,010 & 8.47 & 1,002 & 15 & 1.53 \\
\hline August & 5 & 5,025 & 8.50 & 1,005 & 26 & 2.67 \\
\hline September & 5 & 5,088 & 8.61 & 1,018 & 36 & 3.57 \\
\hline October & 5 & 5,232 & 8.85 & 1,046 & 60 & 5.93 \\
\hline November & 4 & 4,051 & 8.56 & 1,013 & 80 & 8.14 \\
\hline December & 4 & 4,371 & 9.24 & 1,093 & 43 & 4.07 \\
\hline Total & 56 & 55,169 & $100.00 \%$ & 11,824 & - & - \\
\hline
\end{tabular}

$* \mathrm{CV}-$ Coefficient of variation

During the study period, 36 different causes of sentencing between organs and carcasses were identified, with a total of 14,708 condemnations, which generated R\$ 1,221,035.90 of economic losses. Ischemia was the main cause of organ condemnation, with more than 6 thousand pieces, which represents $41.86 \%$ (Table 3). However, with a small economic significance of $\mathrm{R} \$ 22,692.89$ (1.58\%), of total losses (Table 3), considering that the majority condemnations are kidneys, a small value organ in the market (Table 4). The lungs, kidneys and liver had higher condemnation rates, $48.75 \%, 41.66 \%$ and $3.61 \%$, respectively. The lugs' economic losses were $\mathrm{R} \$ 36,242.23(2.87 \%)$ with majority of cases due to pulmonary emphysema. On the other hand, livers' economic losses were R $\$ 32,147.38$ (2.71\%), most frequently by teleangiectasia. 


\section{Macrothink}

Journal of Agricultural Studies

ISSN 2166-0379

2019, Vol. 7, No. 4

In a study carried out in a Pará state's municipality, Gurgel et al. (2017) reported that lung (36.02\%), followed by the liver (25.12\%) and the kidneys $(22.47 \%)$ were the organs that presented the highest condemnation rate, telangiectasia being the higher index cause in livers, and ischemia occurrence in kidneys.

Similar to that observed in the present study, pulmonary emphysema was the most frequent finding in the lungs in a study performed by Almeida et al. (2017). Israel et al. (2014) reported that the lungs were the most doomed organs $(36.10 \%)$, and then the kidneys (29.66\%). Different result found Fruet et al. (2013), in their researches, where the main organ condemned was the liver $(40.46 \%)$, with a higher prevalence lesion due to Fasciola hepática.

The condemnation rates of organs and carcasses did not suffer seasonality in the period of the present study $(\mathrm{F}=0.131$ and $\mathrm{F}=0.330$, not significant $)$.

Tuberculosis was the disease that generated the greatest economic loss, since most of condemned pieces are quarters of carcass or whole carcass, which is the most valued and most consumed. This loss represented almost $3 \%$ of the total, with a financial loss of $\mathrm{R} \$ 872,783.64$. Corroborating with this result Mocci et al. (2014) found a prevalence of $2.4 \%$ in the São José do Rio Preto and São Paulo region, even after 12 years of the National Program for the Control and Eradication of Brucellosis and Tuberculosis in this area. On the other hand, Almeida et al. (2015) observed that tuberculosis was present in $0.0112 \%$ of animals slaughtered, whereas in Turkey Yibar et al. (2015) verified a financial loss of US\$ 239,298.68 (R\$ 910,135.52), for tuberculosis' condemnation.

Adenitis was the pathology that caused the second major economic loss, $\mathrm{R} \$ 155,769.92$ and $0.48 \%$ of prevalence. Bruise was another condemnation cause $(0.23 \%)$, which can be easily controlled by good management. It still is the cause of large financial losses, which was R\$ 72,219.05. Pereira et al. (2013) mentioned a lesions' rate of $73.68 \%$ by bruise in bovine carcasses and Hensi et al. (2014) reported 74.6\%, with a loss of $\mathrm{R} \$ 387,554.67$. Other renal diseases such as uronephrosis, nephritis and renal calculi represented negligible economic losses. 


\section{MInstitute ${ }_{\text {Mnt" }}^{\text {Macrothin }}$}

Journal of Agricultural Studies ISSN 2166-0379

Table 3. Main causes and values of economic losses from carcasses and viscera condemnation, between March 2010 and October 2014

\begin{tabular}{|c|c|c|c|c|}
\hline Cause & Quantity & $\%$ & Economic loss $(\mathrm{R} \$)$ & $\%$ \\
\hline Tuberculosis & 438.75 & 2.98 & $872,783.64$ & 71.48 \\
\hline Adenitis & 71.25 & 0.48 & $155,769.92$ & 12.76 \\
\hline Bruise & 34.00 & 0.23 & $72,219.05$ & 5.91 \\
\hline Emphysema & $4,198.00$ & 28.54 & $25,866.48$ & 2.12 \\
\hline Ischemia & $6,157.00$ & 41.86 & $22,692.89$ & 1.86 \\
\hline Abscess & 202.50 & 1.38 & $22,460.43$ & 1.84 \\
\hline Congestion & $2,628.25$ & 17.87 & $17,419.95$ & 1.43 \\
\hline Unknown & 5.00 & 0.03 & $10,931.23$ & 0.90 \\
\hline Teleangiectasia & 77.00 & 0.52 & $5,618.55$ & 0.46 \\
\hline Contamination & 56.00 & 0.38 & $3,183.94$ & 0.26 \\
\hline Mastitis & 1.00 & 0.01 & $2,186.25$ & 0.18 \\
\hline Perihepatitis & 31.00 & 0.21 & $1,993.09$ & 0.16 \\
\hline Ruminal aspiration & 270.00 & 1.84 & $1,970.16$ & 0.16 \\
\hline Pleurite & 259.00 & 1.76 & $1,486.20$ & 0.12 \\
\hline Malignant melanoma & 1.50 & 0.01 & $1,098.86$ & 0.09 \\
\hline Pericarditis & 41.00 & 0.28 & 822.94 & 0.07 \\
\hline Blood aspiration & 82.00 & 0.56 & 579.38 & 0.05 \\
\hline Lymphadenitis & 0.25 & 0.00 & 546.57 & 0.04 \\
\hline Cirrhosis & 4.00 & 0.03 & 291.87 & 0.02 \\
\hline Fasciolose & 3.00 & 0.02 & 218.90 & 0.02 \\
\hline Jaundice & 5.00 & 0.03 & 163.15 & 0.01 \\
\hline Bleeding & 2.00 & 0.01 & 145.94 & 0.01 \\
\hline Parasitic hepatitis & 2.00 & 0.01 & 145.94 & 0.01 \\
\hline Adherence & 1.00 & 0.01 & 72.97 & 0.00 \\
\hline Hydatidose & 1.00 & 0.01 & 72.97 & 0.00 \\
\hline Enteritis & 1.00 & 0.01 & 47.07 & 0.00 \\
\hline Hemorrhagic Enteritis & 1.00 & 0.01 & 47.07 & 0.00 \\
\hline Parasitic granuloma & 1.00 & 0.01 & 47.07 & 0.00 \\
\hline Urinary cyst & 71.00 & 0.48 & 37.13 & 0.00 \\
\hline Bronchitis & 6.00 & 0.04 & 34.43 & 0.00 \\
\hline Edema & 1.00 & 0.01 & 33.02 & 0.00 \\
\hline Myocarditis & 1.00 & 0.01 & 20.07 & 0.00 \\
\hline Nephritis & 32.00 & 0.22 & 16.74 & 0.00 \\
\hline Uronephrosis & 19.00 & 0.13 & 9.94 & 0.00 \\
\hline Renal calculus & 3.00 & 0.02 & 1.57 & 0.00 \\
\hline Adrenal hypertrophy & 1.00 & 0.01 & 0.52 & 0.00 \\
\hline Total & $14,708.50$ & 100.00 & $1,221,035.91$ & 100.00 \\
\hline
\end{tabular}


Table 4. Condemnation's parts and economic losses' value between March 2010 and October 2014

\begin{tabular}{ccccc}
\hline Item & Quantity & $\%$ & Economic loss $(\mathrm{R} \$)$ & $\%$ \\
\hline Carcass & 516.5 & 3.51 & $1,138,648.22$ & 93.25 \\
Lung & 7,171 & 48.45 & $36,242.23$ & 2.97 \\
Kidneys & 531 & 3.61 & $32,147.38$ & 2.63 \\
Heart & 183 & 41.66 & $8,016.04$ & 0.66 \\
Head & 71 & 1.24 & $3,697.77$ & 0.30 \\
Tongue & 59 & 0.48 & $1,325.34$ & 0.11 \\
Intestine & 10 & 0.40 & 488.54 & 0.04 \\
Spleen & 39 & 0.07 & 400.05 & 0.03 \\
Total & $14,708.5$ & 100.00 & 70.33 & 0.01 \\
\hline
\end{tabular}

In the analyzed period, there was a higher amount of condemnations in the first three years, to both carcasses and organs (Table 5). The year 2012 stands out, with 142 carcasses and more than 4,000 condemned organs, in the total of $\mathrm{R} \$ 330,251.63$ economic losses. By 2013, those figures fell by almost half. The carcass condemnations were estimated at $3.51 \%$ of the total, while the organs, $96.49 \%$. On the other hand, the largest portion of losses was due to carcass condemnations $(93.25 \%)$, because in them are the highest consumption cuts. 
Table 5. Economic loss of quantity and value of organs and carcasses' condemnations, between March 2010 and October 2014

\begin{tabular}{ccccccc}
\hline & \multicolumn{2}{c}{ Carcass } & \multicolumn{2}{c}{ Organ } & \multicolumn{2}{c}{ Total } \\
\cline { 2 - 7 } Year & Quantity & $\begin{array}{c}\text { Economic } \\
\text { loss }(\mathrm{R} \$)\end{array}$ & Quantity & $\begin{array}{c}\text { Economic loss } \\
(\mathrm{R} \$)\end{array}$ & Quantity & $\begin{array}{c}\text { Economic loss } \\
(\mathrm{R} \$)\end{array}$ \\
\hline 2010 & 106.00 & $233,681.92$ & $3,119.00$ & $24,149.97$ & $3,225.00$ & $257,831.89$ \\
2011 & 120.00 & $264,545.57$ & $3,671.00$ & $25,585.88$ & $3,791.00$ & $290,131.45$ \\
2012 & 142.00 & $313,045.59$ & $4,054.00$ & $17,206.04$ & $4,196.00$ & $330,251.63$ \\
2013 & 83.50 & $184,079.62$ & $2,076.00$ & $9,431.35$ & $2,159.50$ & $193,510.97$ \\
2014 & 65.00 & $143,295.52$ & $1,272.00$ & $6,014.44$ & $1,337.00$ & $149,309.95$ \\
\hline Total & 516.50 & $1,138,648.22$ & $14,192.00$ & $82,387.68$ & $14,708.50$ & $1,221,035.90$ \\
\hline$(\%)$ & 3.51 & 93.25 & 96.49 & 6.75 & 100,00 & 100 \\
\hline
\end{tabular}

The lungs and liver were the organs that generated greater economic losses ( $\mathrm{R} \$ 68,389.61)$ (Table 4). Fruet et al. (2013) report a loss of R $\$ 87,108.05 /$ year with organ condemnations. However, in the present study, the bovine carcasses, from which the highest value and income cuts occurred, had an economic loss of $\mathrm{R} \$ 1,144,628.51$, which is equivalent to $93.25 \%$ of the final loss.

The main lesion identified in condemned carcasses was tuberculosis, with a prevalence of $71.48 \%$, which is a bacterial zoonosis. It can be controlled and diagnosed in the field, and also it has a great economic importance when condemning carcasses and causing 10 to $25 \%$ of reproductive efficiency losses on infected animals. There are no updated official epidemiological surveys of bovine tuberculosis prevalence in Brazil, however, in the latter estimate, the data indicated a national average prevalence of $1.3 \%$ of tuberculin reactive animals from 1989 to 1998 (Brasil, 2006). In addition to financial losses, tuberculosis causes damage to public health, since it is associated with occupational disease and raw meat consumption (Veronesi and Focaccia, 2004).

Although the main product inside a refrigerator is the back and front rooms' meat, the byproducts (bovine organs) are important income sources for its economy, thus the condemnations generate direct losses to the company and indirect to the producer (Kale et al., 2011), because animals with compromised organs will not have the same productive and economic performance as the healthy ones. 
The economic losses' ratio by gross revenues were $1.28 \%, 1.17 \%, 1.30 \%, 0.68 \%$ and $0.59 \%$, respectively in the years 2010, 2011, 2012, 2013 and 2014. These results showed that, on average, $1.01 \%$ of the slaughterhouse gross revenue was lost in carcass and organ condemnations. The value that was no longer collected could be invested in improvements, such as a structure for the conditional use of parts destined for treatments by cold, heat or salting and thus commercialized.

Most condemnations suspected of tuberculosis could be avoided if the PNCEBT was implemented in the farm with voluntary adherence and diagnosis in the field through tuberculin testing in cattle. Thus, the decision in the health diagnosis would be more efficient and would not depend only on the visual inspection, which may be flawed; since there are lesions similar to those of TB, such as those for medicines and vaccines. These lesions can be removed and the carcass can be release, according to RIISPOA (Brasil, 2017).

Animals with a tuberculin-positive allergic reaction should be euthanized, a factor that reduces the frequency of infected animals and increases the epidemiological and animal transit control.

The condemned organs that caused greater financial loss were lungs and liver, which can be reduced through preventive measures' application in the productive system. The finding of a considerable amount of condemnation for tuberculosis and adenitis lesions, which cause the greatest economic loss to the companies and to the producers, imposes the need to comply with the voluntary control and eradication programs for bovine tuberculosis. This would reduce the prevalence and incidence of new tuberculosis outbreaks, and also, would certify properties as free or monitored to tuberculosis, through diagnostic methods in field, provided for in the National Program for the Control and Eradication of Brucellosis and Tuberculosis of the Ministry of Agriculture, Livestock and Food Supply.

\section{Acknowledgement}

This study was financed in part by the Coordenação de Aperfeiçoamento de Pessoal de Nível Superior - Brasil (CAPES) - Finance Code 001. We thank the Municipal Thailand Government, Pará, the Associations and Trade Unions, cattle ranchers, the Thailand Slaughterhouse, the Banco do Brasil, the Banco da Amazônia and the Agência de Defesa Agropecuária do Pará, for making fundamental data available for research.

\section{References}

ADEPARÁ Agência de Defesa Agropecuária do Estado do Pará. ()2019. Erradicação da Febre Aftosa [online]. Website http://www.adepara.pa.gov.br [Accessed: 24 May 2019].

Almeida, A. V., Silva, M. L., Santos, R., \& Castro, B. G. (2015). Retrospective study of bovine tuberculosis in slaughter of SINOP, MT from august 2014 to august 2015. Revista de Educação Continuada em Medicina Veterinária e Zootecnia do CRMV-SP, 14(2), 85.

Almeida, T. J. O., Silva, S. C. G., Torres, M. B. M, \& Franque, M. P. (2017). Macroscopic lesions and causes for condemnation of cattle carcasses and viscera in the microregion of 
Garanhuns, Pernambuco, Brazil. Medicina Veterinária (UFRPE), 11(4), 292-300. https://doi.org/10.26605/medvet-n4-1959

Almeida, V. V. S., Oliveira, A. C., Oliveira, H. C., Silva, R. R., \& Lima, Júnior, D. M. (2019). Body weight components of Nellore steers finished in tropical pastures. Acta Scientiarum. Animal Sciences, 41. https://doi.org/10.4025/actascianimsci.v41i1.39005

Brasıl. (2006). Programa Nacional de Controle e Erradicação da Brucelose e Tuberculose Animal (PNCEBT). Manual Técnico. Ministério da Agricultura, Pecuária e Abastecimento, Brasília.188p.

Brasil. (2017). RIISPOA - Regulamento de Inspeção Industrial e Sanitária de Produtos de Origem Animal. Decreto n ${ }^{\circ}$ 9.013, de 29 de março de 2017. 2017. Ministério da Agricultura, Pecuária e Abastecimento: Brasília, 94p.

FGV Fundação Getúlio Vargas. FGVDADOS: informação econômica on-line [online]. Web accessed: http://fgvdados.fgv.br [Accessed: 25 May 2019].

Fruet, A. P. B., Fabrício, E. A., Kirinus, J. K., Scortegagna, A., Dorr, A. C., \& Nornberg, J. L. (2013). Economic losses due to condemnation cattle viscera in slaughterhouse in Santa Maria, Rio Grande do Sul. Revista Brasileira Ciência Veterinária. 20(2), 99-103. https://doi.org/10.4322/rbcv.2014.053

Gurgel, A. V. L., Cirne, L. G. A., Pereira, M. F., Castro, S. R. S., Silva, A. S. L., Neves, K. A. L., ... Carvalho, G. G. P. (2017). Convictions of bovine viscera in the municipality of Itaituba - PA. Agroecossistemas, 9(2), 91-101. https://doi.org/10.18542/ragros.v9i2.5110

Hensi, P. C., Souza, A. L. T. M., Mello, C. A., Schirmmer, M., Americano, M. M. S., Lôbo, A. S. M. T., ... Duarte, S. G. S. (2014). Perdas diretas ocasionadas por hematomas em carcaças de bovinos. Proceedings of the XII Latin American Congress on Food Microbiology and Hygiene, Blucher Food Science Proceedings.Blucher. pp. 433-434. São Paulo. https://doi.org/10.5151/foodsci-microal-221

IBGE Instituto Brasileiro de Geografia e Estatística. (2010). Censo demográfico 2010 [online]. Website https://sidra.ibge.gov.br/Tabela/1309 [Accessed: 24 May 2019].

IBGE Instituto Brasileiro de Geografia e Estatística. (2018a). Pesquisa da Pecuária Municipal. Website https://sidra.ibge.gov.br/tabela/3939 [Accessed: 24 May 2019].

IBGE Instituto Brasileiro de Geografia e Estatística. (2018b). Pesquisa Trimestral do Abate de Animais [online]. Website https://sidra.ibge.gov.br/tabela/1092 [Accessed: 25 May 2019].

Israel, L. F. S., Duarte, M. T., \& Carrijo, K. F. (2014). Main causes of condemnation at bovine slaughterhouse under official inspection service in the city of Rio Branco, Acre State, Brazil. Enciclopédia biosfera, Centro Científico Conhecer, 10(19), 154.

Kale, M. C., Aral, Y., Aydin, E., Cevger, Y., Sakarya, E., \& Güloglu, S. C. (2011). Determination of by-product economic values for slaughtered cattle and sheep. Kafkas Universitesi Veteriner Fakultesi Dergisi, 17(4), 551-556. 
MAPA Ministério da Agricultura, Pecuária e Abastecimento. (2017). Exportação [online]. Website

http://www.agricultura.gov.br/assuntos/sanidade-animal-e-vegetal/saude-animal/exportacao [Accessed 24 May 2019].

MAPA Ministério da Agricultura, Pecuária e Abastecimento. (2018). Mapa da Febre Aftosa [online].

Website http://www.agricultura.gov.br/assuntos/sanidade-animal-e-vegetal/saude-animal/programas-d e-saude-animal/febre-aftosa/mapa-da-aftosa [Accessed: 24 May 2019].

Mocci, D., Renesto, D. M., Rodrigues, A., Silva, R. S., \& Machado, J. G. (2014). Prefalence of bovine brucellosis and tuberculosis diseases in farms in the area of São José do Rio Preto. Ars Veterinaria, 30(2), 100-103. https://doi.org/10.15361/2175-0106.2014v30n2p100-103

Pereira, L. S., Santos, G. C. J., Lira, T. S., Lopes, F. B., Vieira, I. A., Minharro, S., \& Ferreira, J. L. (2013). Influence of pre-slaughter management on the frequency of injuries and characteristics of bovine carcasses from Southern Pará State, Brazil. Revista Acadêmica Ciências Animal, 11(2), 169-178. https://doi.org/10.7213/academica.011.002.AO07

Sarcinelli, F., Venturini, K. S., \& Silva, L. C. (2007). Características da carne bovina. Espírito Santo, Universidade Federal do Espírito.

Silva, J. R. P. L. (2011). Tailândia, Pará. A história do primeiro município a receber a operação arco de fogo. 86p.

US Inflation Calculator [online]. Website https://www.usinflationcalculator.com/ [Accessed: 25 May 2019].

USDA United States Department of Agriculture. (2018). Foreign Agricultural Service [online]. Website https://apps.fas.usda.gov/psdonline/app/index.html\#/app/advQuery [Accessed 24 May 2019].

Veronesi R and Focaccia R. (2004). Tratado de infectologia, $2^{\text {nd }}$ Ed. Atheneu, São Paulo.

Yibar, A., Selkut, O., \& Senlik, B. (2015). Major causes of organ/carcass condemnation and financial loss estimation in animals slaughtered at two abattoirs in Bursa, Province Turkey. Preventive Veterinary Medicine. 118(1), 28-35.

https://doi.org/10.1016/j.prevetmed.2014.11.012

\section{Copyright Disclaimer}

Copyright for this article is retained by the author(s), with first publication rights granted to the journal.

This is an open-access article distributed under the terms and conditions of the Creative Commons Attribution license (http://creativecommons.org/licenses/by/4.0/). 